\title{
TRAINING OF MUSEUM PERSONNEL IN DENMARK
}

\section{Ole Strandgaard}

In August 1966 the Danish Association of Cultural History Museums (DKM) held its annual general assembly in Tønder southern Jutland. On that occasion the leader of the museum in Viborg, Peter Seeberg, who is also a well-known modern author stated that he had written to the Minister of Cultural Affairs on behalf of the museums in Northern Jutland' and proposed that a school for the training of museum staff should be created in Denmark. In the report from this meeting we find the term Museumshojskolen used for the first time. ${ }^{2}$

At that time the new trend was centres. The minister talked about cultural centres as houses where people could be given enlightenment and cultural entertainment. Libraries, concert halls and theatres played a role, but the museums tended to be forgotten. At least they thought so in Northern Jutland and it was in response to this that Peter Seeberg wrote his proposal. It was important to stress that the museums were already in action as cultural centres and used to offering enlightenment. But the rules for granting state money to the museums needed to be changed, it was argued to allow all museums to get $50 \%$ of local grants in state subsidy. All cultural institutions should, in addition to their primary function, contribute to the creation of «living, cultural fields". And to this end, the Danish Museumshøjskole should be founded.
The proposal stated that the purpose of the new institution was to meet the rapidly growing demand for professional staff at the museums in the provinces, at the libraries and at other cultural centres. The main argument for the institution, it was said,was the need to secure well-educated, trained and service-minded employees for the cultural centres that already existed or were to be founded and developed in the near future.

The Museumshøjskole should offer a four-year education programme. Through theory and practice the students should acquire a comprehensive knowledge and training in all the skills that were and are considered necessary to meet the challenges of museum work. For two periods in the study programme the students should receive practical experience at museums.

Among the theoretical subjects to be taught were: the history and prehistory of 
192 Denmark, art history and architecture, history of music, folklore, the natural history of Denmark, history of technology and natural sciences.

Through a series of workshops the students should learn administration, conservation, education and exhibition work and what was called «research techniques» which covered a whole range of important skills: use of archives and libraries, collecting and excavating, photography, surveying and measuring, documentation and registration.

To qualify for the programme students would have to have successfully completed secondary school or further education. Candidates from the institution should qualify for leading posts (except scientific research) at the museums or cultural centres. $^{3}$

The idea of cultural centres never won acceptance and twenty-three years were to elapse before an institution entitled Museumshøjskolen came into being and then it was in a totally different form.

What did happen was that the DKM was granted money for experimental work with vocational training. This is how the famous (at least in Denmark!) summer courses started which gained enormous popularity among the museums.

In the late sixties the great majority of museums outside of Copenhagen and the large cities were still run by volunteers, but the "professionalising" of the museums had started and it could be foreseen that sooner or later all the museums would at least have professionals in charge.

Looking back it is remarkable that the proposal from the DKM meeting imagined a non-academic school. One of the reasons for this is that no one at that time could imagine university-educated academic staff at all museums even the smallest ones as we have today.

But there was also an ideology behind it. "We thought», Peter Seeberg told me later, "that this would result in a widespread boosting of the professional museums by giving a formal competence to the kind of people who had so far managed the museums with good results. The scientific or academic experts should come from the universities of course.»

The idea was to train personnel who could run the smallest museums and be assistants to the academically trained experts in the larger ones.

The first experimental summer course was held the following year and through the years to follow DKM developed its own very distinctive and very popular style.

DKM rented a whole folkehøjskole $e^{4}$ in the summer vacation for ten successive days and then held six classes simultaneously. This first summer which all senior museum staff still talk about with veneration offered courses in: Prehistoric sites, Medieval churches, farmhouses and townhouses. Sixty-seven people assembled and enjoyed a stimulating cocktail made up of equal parts of leisure, hard work day and night, getting to know colleagues, informed teaching and inspiration.

One very important feature of these early courses was, that they brought together high and low, learned and learner, professionals and amateurs under rather primitive circumstances. It had great impact on the museum profession as a whole, that learned doctors listened to craftsmen and farmers with experience and skills in museum work, young students shared 
bathrooms with directors of large museums, janitors had a beer with their superiors and board members sat on school benches together with their curators.

Undoubtedly these courses were decisive for that "esprit-de-corps» which developed throughout these years and characterized the cultural history museums. As it was said (by Peter Seeberg of course): Denmark did not have a "system of museums" (museumsvesen) but a "world of museums» (museumsverden).

Renting a folkehojskole was a practical way of arranging things. And it was the cheapest way to «simulate» the Danish Museumshojskole which was originally meant to be a boarding school. The courses were organized by the committee of the DKM who usually engaged (for a token payment) a colleague from one of the museums to organize the course (together with the secretary of DKM) for a couple of years. Since organizer, teachers (who were colleagues too) and students all had to do this more or less in their spare time the easiest way to do it all was once a year instead of spreading the courses over time.

But the price and the convenience were not the only reasons for renting a folkehojskole. The spirit of that very Danish institution meant something too: the broad approach resting on a sincere wish to give enlightenment to whoever wanted to listen, equal opportunity, belief in the spoken language and the engaged dialogue, the chance to learn through listening and participating - without too much reading.

Many have asked why museology (which this is all about) has never become a subject at Danish universities. It has in fact been taught regularly as a supplementary subject to some disciplines such as ethnology or art history. But only in a few lessons a week in a term and never as a discipline in its own right. You cannot take a degree in museology in Denmark.

I believe that one of the reasons for this is that the museums (at least the cultural history ones) have never really wanted it. And by "museums" I mean the museums in the provinces outside Copenhagen which have for many years played a leading role in the debate especially within the DKM. Museology, seen as the way to manage museums, has been developed by the museums themselves not at the universities. The first generation of university-trained curators has inherited this selfesteem, and since they have had to invent everything for themselves they find it difficult to imagine how university people could possibly teach all this (many of them at least have felt that way). Only within the very last few years has it been possible to spot an interest in museology as a university discipline among younger curators.

The first 1967-course was organized in much the same way as a proper Museumshøjskole wouId have been. Half of the time the students were in the countryside doing fieldwork pursuing one of the subjects mentioned above. The rest of the time they sat together in a classroom and were taught administration, registration of collections, conservation etc. Between times they listened to lectures on the major categories of collections: Glass and porcelain, silverware, weaponry, bourgeois and rustic furniture etc.

During the years that followed this approach changed. Each year DKM offered a range of courses held simultaneously. Each course was independent, only the 
194 evening lectures were common to all courses. But naturally people got together in their leisure time!

After a few years the summer courses were transferred to another folkehøjskole so that new landscapes could be used for the fieldwork. They started in Vester Vedsted, then went to Brandbjerg, Try, Gerlev, Båring, Vallekilde, Danebod, Ry.

Over the years most of the aspects of museum-work were covered, as quoting a few titles from the catalogues shows: Excavation techniques, human remains in archaeological fields, city archaeology, industrial archaeology, preservation of textiles, preventive care of collections, use of photography, electronic data, service and security, budgets and accounts, legislation, use of archives, "the cultural landscape», museum and society, documentation of objects, ethnology, documentation of the present day, museum education, the exhibition, use of film and video, design etc.

The DKM summer courses were a success. At their height more than 200 students participated. Everyone wanted to be there. In the seventies when everything was possible it did not always matter which course you took as long as you attended. To be there was something in its own right. It was even possible for a couple of years to have classes which did not have a specific subject but were called "reconnaissanceclasses». Their aim was to think up new ways forward for the museums.

But as the years went by it became clear that even with such success the original Danmarks Museumshojskole was not coming any closer. Even if each and everyone of the courses were of high quality they did not constitute a coherent or systematic training.
The courses were offered more or less at random reflecting what was considered relevant at the time and were not the result of a planned strategy for improvement of the quality of museum work.

Through the eighties ideas about how a more systematic approach could be achieved began to take shape and a special committee was created with the purpose of planning the future vocational training for the museums. In 1989 DKM together with the Danish Art Museums Association (FDK) and the Association for Natural History Museums (DNM) started the Museumshøjskole as an independent institution.

The idea was to gain recognition for this new institution from the Ministry and the Parliament so that it could receive state grants through the legislation governing the museums which was rewritten that year. The committee managed to get the Museumshøjskole included in the law and a yearly allowance was set aside - but far from what was wanted.

The committee and the museum associations had wanted a residential institution with a permanent staff of teachers, they got positions for a leader and a part-time secretary. But it was a start. However small the staff, it was there and could use its time fully. The courses were no longer managed as a sideline but could be given full attention.

The Museumshojskole is an independent institution with its own board or executive committee. You can say that it was founded and run by the museums - but supported by state grants, just as the majority of the Danish museums are.

The board has seven members, three of them appointed by the associations, one 
from each, one is appointed by the State Museums Council, and three are appointed by the Museumshøjskoleforening, an association for museum employees started at the same time as the Museumshøjskole. This association ensures that ordinary staff members have an influence on the training offered.

The new institution did not change things overnight. Since there was not enough money to run a proper school, its activities are in many ways a continuation of the old summer course programme. There are however some important differences.

It appears that the students today prefer short courses to long. Big courses with many classes together do not appeal the way they used to. Consequently we now offer many short courses spread over the calendar rather than big gatherings once a year.

The main reason for this change can be found in the growing awareness about using the museums' resources in a responsible way. The museums want value for their money!

Another reason is that the museums today are subjected to demands from all sides for more and better services. The staffs simply do not have time for extra work.

An investigation recently carried out by the Museumshojskole into how the museums use vocational training seems to confirm this. It appears that the museums which do not use any money on courses, do not use free courses either ( e.g. provided by the trade unions or the municipalities).

This could indicate that the price of the courses is of minor importance. It is true in the sense that the quality of the courses seems to be more important than the price, but to judge from the remarks we get about prices in general, it is evident that courses cannot be too cheap!

Another change which has taken place is that courses increasingly fit together into a modular system. Such courses are repetitive, with a fixed programme, and aim at giving a specific target group, e.g. administrative personnel a basic training.

This current more goal-oriented approach results in more students (517 in 1994) than attended the popular summer courses.

During the last year or two we have worked hard on further planning. What should the future Museumshøjskole be like? The reason for this ongoing planning is that we have still not got the Danish Museumshøjskole envisaged by our founding fathers in 1966 !

After numerous meetings and discussions with the museums we have settled on a model that ensures a reasonably cheap but efficient school:

First of all more of the courses (roughly half those given in the future) must constitute a coherent, modular pattern which will give the individual employee the training he or she and their museum want. A typical set of modules will cover seven to twenty-six days depending on the work in the museum.

The modules accordingly should be graded to fit various levels and should cover the basic skills required of most posts in the museums. They should be offered often enough to ensure that all employees can attend them within the first one or two years after employment.

Modules will be created for the following groups of museums workers: 
196 1) administrative staff, 2) assistants and technicians, 3) curators, educational staff and managers, 4) attendants and guards, cleaning personnel.

The planning and deployment of the modules will take place within the next few years and be completed by 1999. A committee for each of the sets of modules will be appointed. It is our hope that the modules if well executed will set a standard in the years to come so that all employees will be expected to attend them.

We need to have our own building or rooms to house classrooms, laboratories, workshops, administration and library (The Museumshojskole owns and runs a very competent museological library which is at the moment housed by the National Museum in Copenhagen).

Easy access to appropriate equipment and the ability to plan the courses without the restraints imposed by availability of rooms are of the utmost importance for carrying through a complicated network of modules.

But we do not want our own residential institution since this will be too expensive to run. Instead we envisage a position close to other training centres or hotels where lodgings could be arranged. We also want close cooperation with nearby museums and university institutes. This calls for a position in one of the cities.

The staff of the Museumshojskole should be enlarged with two extra permanent positions - someone to be responsible for the maintenance of the modules and an assistant or a janitor to take care of all the practical jobs. The teachers will be parttime and engaged on a temporary basis.

It is very important not to lose the inspiration of the folkehojskole concept.
No one wants the training offered to be compulsory. It is also very important to maintain the possibility of arranging courses which reflect the current situation.

It is important to the museums that the training should never become a demand or a condition for employment. The museums want to be free to choose their personnel but at the same time they want good courses to offer the staff once they are employed.

The training provided by the Museumshojskole should not become a grinding duty but must, even in the future, be an inspiration and a helping hand. Therefore the more "bread-winning" modules will be supplemented with "free» courses and seminars, experimental, reflective, innovative, sometimes with teachers from abroad.

The Museumshøjskole wants to maintain a role in the development of museology in Denmark. This will be achieved through the courses and seminars but also through the museological lectures given once a year and through developing the museological library. We also want to establish cooperation with the universities.

The Danish museums law is once again in the process of being revised and once again we struggle to get the Museumshøjskole improved. All three museum associations and the State Museums Council agree on the model.

So we are optimistic and believe that we are now close to achieving our goal! 
NOTES

1. "Museums in Northern Jutland» were: Vendsyssel Historiske Museum in Hjørring with Palle Friis, Aalborg Historiske Museum with Peter Rismoller, Viborg Stiftsmuseum with Peter Seeberg and Kulturhistorisk Museum i Randers with Bjorn Stïrup.

2. This general assembly in the DKM is famous for another reason. Peter Seeberg also suggested that the museums should establish a Telex network so that information could circulate speedily among the museums. Now that fax machines and computer networks are ordinary household goods it does not sound such an innovation but at that time it was visionary. An anecdote from the meeting:

Peter had forgotten his manuscript and therefore had it sent to the hotel where the meeting took place as a telegram. It cost him a small fortune but it demonstrated nicely the potential benefit of modern telecommunication and took everyone by surprise (information from Palle Friis, Vendsyssel Historiske Museum).

3. As the report from the meeting is a historical document almost a museum classic the part dealing with the Museumshojskole follows here - in Danish:

Uddrag af referat fra Dansk kulturhistorisk Museumsforenings repræsentantmøde på Hotel "Tønderhus», fredag den 26, august 1966, kl.

9.00 .

Under diskussionen efter formandens beretning fremlagde Peter Seeberg de til kulturministeren indsendte kulturcenterkommentarer fra de nordjydske museer, hvori det bl.a. hedder:

1. at revidere tilskudssatserne for kultrelle institutioner så der opnås ensartethed ved et minimum på halvtreds procent. At muliggøre denne ensartetheds gennemførelse ved kravet om fremskyndet, detailleret budgettering.
2. at understrege og tilskynde at alle kulturelle institutioner udover deres specialfunktion medvirker til skabelsen at et levende kulturelt felt.

3. at oprette en Danmarks Museumshøjskole som en uddannelsesmæssig baggrund for udbygning af de kulturelle institutioner.

Vedrørende museumshøjskolen har kulturministeren modtaget følgende forslag:

"Med det formål at imødekomme et hastigt stigende behov for medarbejdere ved provinsens museer, biblioteker og andre kulturcentre, foreslås oprettelsen af DANMARKS MUSEUMSHØJSKOLE. MUSEUMSHØJSKOLEN skal gennem en fire års uddannelse af praktisk teoretisk art give eleverne en omfattende baggrund af kundskaber og solid erfaring i færdigheder, som må anses for nødvendige til at bestride museumsmandens alsidige gerning.

Uddannelsen tænkes at foregå i form af forelæsninger $i$ en række grunddiscipliner (herunder registrering, undersøgelsesarbejde, udstillingseksperimentelt arbejde mv) - samt $i$ to perioder praktik ved et eller flere kulturcentre. Følgende discipliner tænkes gennemgået i forelæsninger og øvelser: Danmarks forhistorie og historie - Kunsthistorie og arkitektur Musikhistorie - Folkelivsforskning - Danmarks naturhistorie - Teknologiens historie og naturlære. Igennem værkstedsarbejde tænkes indøvet færdigheder i: Administration - Forskningsteknik Konservering - Publikumsvirksomhed. Lærerkollegiet tænkes opdelt i: undervisningsledere (forelæsninger i grunddiscipliner og ansvar for disciplinens forskningsprogram) undervisningshjælpere (øvelser og ledelse af elevernes praktiske træning). Undervisningen tilrettelægges i videst mulig grad således at de teoretiske kundskaber vindes i kontakt med eller under udøvelse af praktisk arbejde. Dette praktiske arbejde skal 
198 kunne udgøre en klart omskrevet detaille i et forskningsprogram for en eller flere grunddiscipliner.

Adgangsberettigede er ansøgere med realeksamen eller højere uddannelse. Afgang fra skolen berettiger til ansættelse i og avancement til ledende, ikke videnskabelige stillinger ved landets museer og øvrige kulturcentre.

Baggrunden for forslaget om DANMARKS MUSEUMSHØJSKOLE er et ønske om i tide at sikre veluddannede, praktisk trænede og publikumsvendte medarbejdere ved de kulturcentre som findes eller snarest oprettes og udbygges i provinsbyerne.

Det må forudses at en vis specialisering af uddannelsen efter en opbygningsperiode for provinsens kulturliv vil blive påkrævet og da føles naturlig.

\section{Øvelser og varkstedsarbejde:}

1) Administration (herunder samarbejdsteknik).

2) Forskningsteknik

Arkiv- og biblioteksstudier.

Indsamlings- og udgravningsteknik.

Opmåling og fotografering.

Registrering.

3) Konservering (herunder emballering, transport mv.).

4) Publikumsvirksomhed (udstillinger, koncerter, teaterforestillinger).

Man enedes om at genoptage diskussionen ved et senere møde. som bestyrelsen skal indkalde til.»

4. In the pamphlet «The Danish Folkehøjskole Today» The Folkehøjskole Association says: «The term folkehojskole (or højskole) is often translated as folk high school or folk college. Neither of these terms adequately covers the concept. The folkehøjskole is neither a high school, nor a college.

"Folk» (folk, ordinary people) is the most important part of the word. The substance of the word cannot be translated into other languages. The meaning cannot be conveyed by using the English «folk» or "public». In its various combinations, the word contains a philosophical, educational, social, and political idea created by N.F.S. Grundtvig. Folk-in its Danish context, just like the words "fate» and "feeling", is difficult to locate in the linguistic landscape. It lies deep in Danish ideas and actions." What is then a folkehojskole? A folkehojskole is a free (independent) boarding school providing adult education and what Grundtvig called lifeenlightenment. It is open to all, it is reasonably cheap since it is state subsidized, is does not give any specific education and you cannot take examinations from it. Its primary value is the opportunity it offers everyone to develop their own intellectual faculties. The teaching rests on a belief in the value of "the living, spoken word". These schools are very different and can deal with all kinds of subjects: art, history, philosophy, sports, music, etc. There are about 100 schools of the type in Denmark. In 1990 approx. 14000 students took long courses (half a year) and approx. 45000 short courses (a fortnight).

Ole Strandgaard, M.A. Anthropologist with fieldwork in Northern Norway and India, 19 years experience as curator in large and small museums, head of Museumshojskolen since 1989.

Adr: Museumshojskolen, Jyderupvej 18, DK-4560 Vig,

Fax: $+45-53417210$. 